\title{
FEATURES OF THE INTELLECTUAL CAPITAL WITHIN ROMANIAN SMES
}

\author{
Andreea Feraru \\ "Vasile Alecsandri” University of Bacău \\ andreea_feraru26@yahoo.com
}

\begin{abstract}
Intellectual capital has become a key element of the knowledge economy and the knowledge economy, which includes today even the SMEs from Romania, alongside with other types of organizations, puts a great emphasis on the exploitation of the intellectual capital. The SMEs employees create a constructive work environment, they manifest a mutual trust and most of them have an appropriate work behavior conforming to the internal standards. The jobs and the teams formed inside the analyzed SMEs are stimulating the development of the intellectual skills, which reduces the need of involving external experts, appealing those experts would transform tacit knowledge into explicit knowledge. The organizational communication provides the necessary information for the employees and contributes to the establishment of certain fair and effective relationships between managers and employees, between colleagues, but also with the people outside the organization.
\end{abstract}

\section{Keywords}

knowledge; economy; models; organizations; intellectual capital

\section{JEL Classification}

F15, M1, M10

\section{Introduction}

The economic environment where the SMEs are competing is in a continuous process of changing. Switching from a post-industrial based economy to a knowledge based economy has changed the way the small businesses manage their assets. The knowledge based economy, which includes today even the SMEs from Romania, alongside with other types of organizations, puts a great emphasis on the exploitation of the intellectual capital. Each country, company and individual depends increasingly more on knowledge, which materializes in: patents, skills, technologies, and customer information about suppliers. At the level of SMEs, the technology and the associated processes act on the individual knowledge, and especially on the side of the intellectual tacit component. The management and the leadership are a powerful integrator in the nonlinear segment. The leadership is important by its power to act on knowledge, on the intelligence and on the individual values. The organizational vision and mission are also interesting integrators, which act mainly on the individual emotional intelligence. The organizational culture appears as a powerful integrator, since it acts mainly on the individual intelligence and on the values, creating models of the organizational behavior.

\section{Features of the intellectual capital}

Most authors examine intellectual capital from a static perspective and focus on the development of its various evaluation models. In this chapter we surveyed the classical static models: Sveiby, Edvisson, Balanced Scorecard, as well as the canonical model of intellectual capital. 
Among the group of static models for evaluating organisational intellectual capital the canonical model stands out. This model enables the structuring of organisational intellectual capital in: human capital, structural capital and relational capital. Although the model is widely spread, it is a static one and can thus create a series of errors in the process of evaluation, because all the three entities mentioned above are not independent from the viewpoint of their contents, as any logic of structuring complex entities requires.

As proved by the almost comprehensive analysis carried out by Andriessen (2004) and, more recently, by Roos and Pike (2007), most authors interpret intellectual capital as organisational potential structured in the following manner: human capital, structural capital and relational capital. No matter what designations they might use, static models approach the manifestation of organizational intellectual capital after its foundation (Stewart, 1999; Roos et al., 1997; Sveiby, 1997; Andriessen, 2004).

That is why all this research has a static character, examining a taxonomy reflecting a type of fixed reality, and not one which is dynamic and changing. In the context of a continuously changing and evolving economy, the most important resource for any enterprise is its human capital. However, the simple existence of a number of employees is not sufficient for making the difference in value between one organisation and another; what represents and constitutes its competitive advantage is the quality of its personnel, their competences, abilities, knowledge and their performance- and success-oriented views.

Could we say that the implication of performance-oriented employees and the existence of a work environment which stimulates creativity and innovation are enough for long-term business success? Certainly, this is not enough because an organisation does not operate by itself, it functions in a certain context and establishes relations with various actors of the organisational environment (stakeholders, clients, suppliers, shareholders, state institutions etc.). That is why the relational component of intellectual capital is as important as its human and structural components. An organisation must concentrate its financial and human efforts on building and maintaining long-term relationships with all its business partners, with the target market and with the society in general.

Leif Edvinsson, in line with the scheme of market value, divides intellectual capital in human capital and structural capital which, in its turn, is formed of client capital and organisational capital, the latter comprising innovation capital and process capital. Although this classification seems to be well-structured, it makes use of groups of entities which are not defined rigorously and do not possess unique features.

Sveiby's model divides intangible assets in external structure, internal structure and individual competences.

As far as the external structure is concerned, we must mention that it refers to clients, suppliers and other stakeholders who are considered relevant for a certain company. Depending on the type of organisation, the external structure will differ from one enterprise to another. The internal structure refers to systems, databases and processes which support the organisation, whereas individual competences concern the employees' individual experience, knowledge, competences, abilities and ideas.

The model developed by Norton and Kaplan does not present intellectual capital from the perspective of its components. The Balanced Scorecard model analyses an organisation from four perspectives: that of learning and development/growth, internal processes perspective, clients' perspective and financial perspective, a model which largely resembles some of the classifications of intellectual capital centred on components which were exposed above.

In a spectral dynamic analysis, organisational intellectual capital is structured in: organisational knowledge, organisational intelligence, organisational values, and their value is built on certain mechanisms entitled integrators, whose chief 
constitutive elements are: individual knowledge, individual intelligence and individual cultural values.

The following elements can be part of the general designation of organisational knowledge: values, beliefs, rituals within the organisation, organisational culture, knowledge stored in existing software, licenses, patents, or in organisational databases. Other elements are added to these, such as the tacit and explicit knowledge of the organisation members, knowledge which is used in daily activities and processes. According to a simple analysis, we could affirm that organisational knowledge includes tacit and explicit knowledge, but this knowledge dyad is replaced with a new perspective: that of cognitive knowledge, emotional knowledge and spiritual knowledge.

In order to understand this new manner of approaching knowledge, we will make a brief presentation of this perspective. Specialists in Eastern Europe replaced the Cartesian mind-body duality with a unitary conception regarding knowledge; this means that both cognitive and emotional knowledge can change continuously from one form to another by virtue of the thermodynamics metaphor.

While Western philosophy excluded affectivity from the class of knowledge because of its subjective nature, Eastern philosophy extended the scope of knowledge to include affectivity as well, and this is an important element for leadership because employees are motivated especially by means of emotional knowledge. At the same time, innovation is based on intuition, which has both a cognitive and an emotional character.

Cognitive knowledge is regarded as the direct result of the cognitive process, since they comprise the rational part of the cognitive process. Cognitive knowledge contains both rational and non-rational knowledge, so it would be a mistake to consider the spectrum of cognitive knowledge only from the perspective of rational characteristics. Emotional knowledge is based on emotions which occur before cognitive processes and they influence the way in which we process information. Emotional knowledge shows resemblance both in contents and intensity with the two dimensions of thermodynamic energy.

Spiritual knowledge contains the most profound significations, values, objectives and the highest motivations, both at individual and organisational levels. Spiritual knowledge is held in common by all employees and they generate the necessary motivations for their efforts to accomplish a durable competitive advantage. The vision and mission of an enterprise are strongly supported by corporate values, which are integrated in the field of spiritual knowledge.

Each employee enters an organisation possessing his/her own collection of cognitive, spiritual and affective knowledge. These types of individual knowledge can be shared, transferred or employed directly in the decision-making process, resulting from the action of organisational integrators.

One of the most important problems for each organisation is that of integrating employees' individual knowledge and intelligence so as to create organisational knowledge and intelligence. In order to achieve this aim, an organisation needs some specific mechanisms for the generation of synergies.

This fact is true because in non-linear systems, as in the case of knowledge, the outcome means more than the simple addition of individual achievements. Each type of knowledge can be processed by a specific kind of intelligence, so that we obtain a final result for the entire organisation, namely the organisational intellectual capital.

Organisational intelligence - a component of the intellectual capital possessed by each member of the enterprise - has an important contribution to organisational intellectual capital. The processing of knowledge is performed with the help of intelligence and decisions taken make use of the values of organisational culture as 
guiding factors. Organisational values are composed, in their turn, of cultural values and business values.

Additionally, while analysing the entropic model, we also investigated the influence of major integrators on intellectual capital, with its three components: cognitive capital, emotional capital, spiritual capital, as well as the field of factors which exerts force on the primary components of intellectual capital - knowledge, intelligence and values - and determines the generation and development of intellectual capital.

\section{Conclusions}

In the last decades, the world economy has undergone profound economic changes that were reflected in how economic factors affect productivity. So we exchanged the traditional economy based on resources tangible: land, investment of buildings, capital and labour, into an economy based on intangible assets with financial accounting difficult and high impact on productive performance of organizations.

Intellectual capital is perceived as an important factor of the success of an organisation. Intellectual capital as a dynamic approach focuses on the development of entropic model - which captures the dynamic transformation of intellectual capital into usable intellectual capital.

Also, was analyzed the influence of the main integrators intellectual capital, divided into three components: cognitive capital, emotional capital, spiritual capital, and fields of forces acting on the primary constituent of intellectual capital - knowledge, intelligence and values - and determines the generation and development of intellectual capital among SMEs that were analyzed.

This study analyses the stage of knowledge of intellectual capital and focuses on the importance and benefits generated by the intellectual capital and knowledge management.

\section{References}

Al-Ali, N., (2002), All about Intellectual Capital, Comprehensive Intellectual Capital Management.

Albrecht, K. (2003) The power of minds at work. Organizational intelligence in action, American Management Association: New York.

Apetroae, M. (2002), Către o economie bazată pe cunoaştere, UEFISCSU, București.

Bârgăoanu, A., Negrea, E., Călinescu, L. (2007), Project-oriented university - an emerging concept, Management \& Marketing, 4(4), 55-64.

Becker, G. (1997), Capitalul uman. O analiză teoretică şi empirică cu referire specială la educaţie, Bucureşti, Editura All.

Bouchardy I. (2010), Quality strategies: what are french universities. Looking for?, Management \& Marketing, 5(1), 39-56.

Brătianu, C. (2005), Schimbarea de paradigmă în managementul universitar românesc, Revista de Management şi Inginerie Economică, 4 (3), 7-23.

Brătianu, C. (2006), Un model de analiză a capitalului intelectual organizaţional, Management \& Marketing, 1(3), 17-32.

Brătianu, C. (2008), Leadership and management in the transition romanian higher education system, Management \& Marketing, 4(2), 21-36.

Brătianu, C., Jianu I. (2007), The vision and mission of the university. Case study, Management \& Marketing, 4(2), 37-46.

Brătianu, C., Lefter, V. (2001), Managementul strategic universitar, Bucureşti, Rao.

Brătianu, C., Vasilache S. (2009), Evaluating linear-nonlinear thinking style. For knowledge management education, Management \& Marketing, 4(3), 3-18. 
Brătianu, C., Vasilache S. (2009), Implementing innovation and knowledge management in the romanian economy, Management \& Marketing, 4(4), 3-14.

Drucker, P. (1999), Knowledge Management in California, Management Review, 41(2).

Dumitrescu, M. (2001), Strategii şi management strategic, Ed. Economică, Bucureşti.

Feraru A. (2009), The concept of knowledge and knowledge the management in the Romanian business field, Studies and Scientific Researches - Economic Edition, 14, 137-141.

Feraru A. (2010), Knowledge management within organisations, Annals of the Oradea University. Fascicle of Management and Technological Engineering, Volume IX (XIX), 1, 157-160.

Feraru, A., Mironescu R. (2012), Intellectual Capital as a Basic Resource for a New Organizational Behavior And Economic Development, Proceedings of the 4rd European Conference on Intellectual Capital, Arcada University of Applied Sciences, Helsinki, Finland.

Feraru, A., Mironescu R. (2012), The intellectual capital and the learning organization, Journal of International Scientific Publication, Economy \& Business, Bulgaria, ISSN 1313-2555, 6(3), 30-40.

Feraru, A., Mironescu R., Drob C. (2013), Particular Aspects In Intellectual Capital Management of the Romanian SMEs, Proceedings European Conference on Intellectual Capital University of the Basque Country, Bilbao, Spain.

Fox, T., Ward, H., Howard, B. (2002), Public Sector Roles in strenghthening corporate social responsibility, A baseline study, World Bank, October, 1-5.

Kelleher, D., Levene, S. (2001), Knowledge Management: A Guide to Good Practice, PWC, New York.

Kim, C., Manborgue, R. (2003), Fair Process: Managing in Knowledge Economy, Motivation People, 1.

Matmati, M. (2004), Les effets sociaux des TIC et NFO et leurs liens avec la responsabilite sociale de l' Entreprise, La Revue Technologique, IV(1), 97-119.

Nicolescu, O., Nicolescu, L. (2005), Economia, firma şi managementul bazate pe cunostinţe, Ed. Economică, Bucureşti.

Nonaka, I., Takeuchi, H. (1995), The Knowledge Creating Company: How Japanese Companies Create the Dynamics of Innovation. Oxford University Press, New York.

Petrash, G. (2002), Knowledge Management. Classic and Contemporary works, Masschusetts Institute of Tehnology.

Roşca, Ion Gh., Păunescu C., Pârvan, C. (2010), Shaping the future of higher education in Romania: Challenges and driving factors, Management \& Marketing, 5(1), 57-70.

Scârneci, F. (2011), Who are the romanian managers and how they identify themselves?, Management \& Marketing, 1.

Vasilache, S. (2008), Organizational knowledge dynamics, Management \& Marketing, 2. 